\title{
Effects of Covid-19 pandemic on agri-food production and farmers
}

\author{
Atnan UĞUR ${ }^{1 *}($ D), Tuğba BURUKLAR² (D)
}

\begin{abstract}
The Covid-19 pandemic significantly affected agriculture and various industries. This study was conducted to determine the effects of Covid-19 pandemic on agri-food production. The data for this descriptive study were collected from those working in agriculture industry in Konya province of Turkey in between 15/12/2020 and 30/12/2020. These data were collected by a survey form prepared by the researches in line with the existing literature. Descriptive statistics and chi-square test was used to analyze the data. In the research area, it was also found out that median educational status was secondary school graduation and generally the incomes exceeded the expenses. $1.3 \%$ of the participants were diagnosed with Covid-19. Increase in production costs, price instability and difficulties in working and recruiting workers and shrinkage in markets were frequently mentioned by those dealing with dry farming, irrigated farming and vegetable and fruit growing respectively. As income level increased, the level of those worrying about the harvest and sales, experiencing difficulties in agricultural products and food and having problems for supply of production materials also increased. Governments should take measures to take the sting out of the pandemic and they should develop policies/strategies supporting sustainability of agricultural production.
\end{abstract}

Keywords: agriculture; farmer; food; health; supply.

Practical Application: Covid-19 affects agricultural production in different ways.

\section{Introduction}

Epidemics and pandemics are threats deeply affecting human life and bringing deathly consequences. Covid-19 pandemic has lately been at the top of the global agenda due to its effects. Emerging in Wuhan, China in December 2019, Covid-19 has spread like wildfire and affected 217 countries as of now. According to the data of 17 January 2021, total number of confirmed cases is 92.506 .811 and death toll is 2.001.773. USA, India and Brazil take the first three places in terms of number of cases. These countries are responsible for $45.36 \%$ of total cases and $37.20 \%$ of death toll. On the other hand, 1.558.777 Covid-19 cases and 23.664 relevant deaths were stated in Turkey (World Health Organization, 2021). This virus significantly threatens those having cardiovascular and chronical lung diseases and death toll increases day by day (McDonald et al., 2020).

Covid-19 outbreak influences the social life in various dimensions. Three prominent changes caused by the pandemic throughout the globe are decrease/cessation in/of mobility, increase in uncertainties/instability and new behaviors related to concerns about health. Covid-19 outbreak has shown that the nations have fallen short of dealing with global crises. Although vaccination programs against the virus are implemented all over the world, the rate of full dose vaccination is $6.2 \%$. Agricultural production in this period started under the Covid-19 restrictions, although the restrictions were slightly reduced. Currently, it is tried to fight against the pandemic by taking measures such as social distance, mask wearing, individual and mass isolation and travel restrictions. Numerous problems have arisen and uncertainties have increased throughout the pandemic (Mishra et al., 2021). People's going to the groceries in masse following the first curfew announcement in Turkey within the scope of Covid-19 measures clearly evinces the said uncertainty felt by the society. While the effects of Covid-19 are discussed, boom in global population and access to safe and sufficient food still faces us as one of the most significant problems of this century (Fróna et al., 2019). Although it is always critical, the significance of healthy and sufficient nourishment has been understood more during the pandemic. Today, 820 million people are on the breadline and approximately 2 billion people experience mild and severe food insecurity. The conflicts as well as political and economic instabilities going on at several spots in the world make it difficult to have a stable life. On the other hand, agricultural production is threatened by various factors such as droughts or excessive precipitations, greenhouse effect, misuse of agricultural lands, over-divided land structure, use of fossil fuels, insistence on traditional production, problems in mechanization, increase in the need for agricultural water, and young population's avoiding agriculture due to migrations and increase in input costs (Tao et al., 2003; Finger \& Schmid, 2008; Masood et al., 2012; Popp et al., 2014; Konapala et al., 2020; Roell \& Zurbriggen, 2020).

Turkish Ministry of Agriculture and Forestry has taken certain actions such as granting additional seeds, decrease in land allocation prices of the Treasury, making the services of E-Agriculture platform more active, encouraging consumption

${ }^{1}$ Department of Horticulture, Faculty of Agriculture, Ordu University, Ordu, Turkey

${ }^{2}$ Department of Plant Protection, Graduate School of Natural and Applied Sciences, Çanakkale Onsekiz Mart University, Terzioğlu Campus, Çanakkale, Turkey

*Corresponding author: atnanugur@gmail.com 
of fish stocks and training the agricultural laborers on hygiene to ensure that agricultural production is not affected and a healthy food chain is maintained. Agriculture industry is one of the most significant industries of the world with regards to nourishment of people and its commercial value and is deeply related to food safety (Nesheim et al., 2015; Lopez-Ridaura et al., 2019). During the previous outbreaks such as HIV and Spanish flu, problems such as labour loss due to death, not being able to go to the agricultural land, difficulties in recruiting laborers and problems in accessing to healthy food were experienced (Kerkhoven, 1997; Were \& Nafula, 2003; Vass, 2005; Steege et al., 2009; Karlsson et al., 2014; Obrizan et al., 2020). The greatest difficulties brought by the Covid-19 outbreak are price increases in fresh food prices in large and developing densely-populated cities and disruptions in accessing to staple food (Lal, 2020). However, the scale of actual and prospective damages of Covid-19 in economy is not exactly known as its ending date is not clear as of now. The outbreak affects the countries to different extents depending on endurance of their health systems and no region of the world can be entirely protected currently (Sharma et al., 2020). Social distance and quarantine measures are generally preferred to keep the outbreak under control (Barichello, 2020). Some of the decisions/restrictions applied to prevent contagion of the pandemic affect the agricultural activities, agricultural product supply chain and marketing channels (Mishra et al., 2021). These measures also have brought along the risk of losing the informal laborers and seasonal agricultural laborers due to decrease in demand. In Turkey, no restriction specific to those working in agriculture has been imposed in Turkey during the pandemic. However, the curfew for those under 20 and over 65 years of age has restricted the mobility of agricultural laborers in these age groups. This restrictions and procedures specific to the pandemic have directly or indirectly affected agricultural activities. The measures implemented against Covid-19 such as social distance and travel restrictions have affected the agricultural activities due to decrease in labour, difficulties in supply of seeds and feeds, failure in marketing perishable fresh products and difficulties in accessing to the end customers(Barichello, 2020; Poudel et al., 2020; Zhou et al., 2020). This study was carried out to determine effects of Covid-19 pandemic on agricultural production activities.

\section{Material and methods}

This descriptive study was conducted on those working in agricultural activities. Konya province, where the study was carried out, ranks first in Turkey in terms of size of agricultural lands with its farming area of 1.876.344 ha. The farming area of Konya constitutes $8.12 \%$ of total farming areas in Turkey. Arable crops such as wheat, barley, sugar beet, dry bean, potato, sunflower, poppy and corn as well as horticultural crops such as carrot, cherry and sour cherry are grown in Konya province in significant volumes (Konya, 2020). The data of the study were collected by the researches through face to face surveys in between 15.12.2020 and 30.12.2020. A questionnaire prepared by the researches in line with the relevant literature and consisting of 40 questions (10 questions about sociodemographic characteristics and 30 questions about Covid-19 and its effects on agriculture) was used in the study. Power analysis was performed for the study sample size. There are 90.000 farmers in Konya. The farmer sample size was 164 with $80 \%$ confidence level and 5\% error (Dean et al., 2021). As a result of the survey, 14 questionnaires were not taken into consideration because they were filled incompletely and the study was completed with 150 people. Oral and written consent was obtained from 150 people who agreed to participate in the study. The data was assessed with SPSS 20.0 statistics software and descriptive statistics and chi-square tests were used. The significance level of 0.05 was adopted for the research.

\section{Results}

This section may be also divided by subheadings. It should provide a concise and accurate description of the experimental results, their interpretation as well as the experimental conclusion that can be drawn.

\subsection{Sociodemographic characteristics of agricultural laborers}

The sociodemographic characteristics of agricultural laborers participating in study are given in Table 1.

The average age of the agricultural laborers participating in the survey is $53.95 \pm 14.92$ and 91.3 of them are male. $55.3 \%$ of agricultural laborers are primary school graduate; $68.7 \%$ of them have incomes exceeding their expenses; $72.0 \%$ have nuclear families; $55.3 \%$ deal with dry farming; $90 \%$ is grower and $72.7 \%$ predominantly work in summer (Table 1).

\subsection{Covid-19 characteristics of agricultural laborers}

The Covid-19 characteristics of agricultural laborers participating in the study are given in Table 2.

Only $1.3 \%$ of those participating in the research were diagnosed with Covid-19 and $74.7 \%$ had acquaintances diagnosed with the disease. $86 \%$ of those participating in the research received information on Covid-19 and source of this information was visual media for 48.1 of the participants. It was found out that $91.3 \%$ of the participants considered Covid-19 as a contagious disease and $93.3 \%$ of them observed mask wearing, social distance and hygiene rules. $83.3 \%$ of the research participants did not feel safe themselves against Covid-19 (Table 2).

\subsection{Effects of Covid-19 pandemic on agricultural production activities}

The considerations regarding impact of Covid-19 pandemic on agricultural production activities of the agricultural laborers participating in the study are given in Table 3.

It was identified that $88 \%$ of those working in agriculture industry worried about the harvest and sales and these worries were mostly (35.6\%) caused by price instabilities. $91.3 \%, 57.3 \%$, $76.0 \%, 80 \%, 70.7 \%, 89.3 \%$ and $77.3 \%$ of those participating in the study respectively declared that their production pattern was not affected during the Covid-19 pandemic; their idea of working in agricultural industry was not affected; their sowing/ planting time was not delayed; they had difficulties in working and recruiting seasonal laborers; productivity and quality was 
Table 1. Sociodemographic characteristics of agricultural labourers.

\begin{tabular}{|c|c|c|c|}
\hline \multicolumn{2}{|c|}{ Sociodemographic Characteristics } & $\mathrm{n}$ & $\%$ \\
\hline Age & & \multicolumn{2}{|c|}{$53.95 \pm 14.92($ Min:18; Max:85) } \\
\hline \multirow[t]{2}{*}{ Gender } & Female & 13 & 8.7 \\
\hline & Male & 137 & 91.3 \\
\hline \multirow[t]{4}{*}{ Education } & Primary school & 83 & 55.3 \\
\hline & Middle school & 39 & 26.0 \\
\hline & High school & 17 & 11.3 \\
\hline & University & 11 & 7.3 \\
\hline \multirow[t]{3}{*}{ Income level } & Income exceeds expenses & 103 & 68.7 \\
\hline & Income equals expenses & 35 & 23.3 \\
\hline & Expenses exceed income & 12 & 8.0 \\
\hline \multirow[t]{3}{*}{ Family type } & Nuclear family & 108 & 72.0 \\
\hline & Extended family & 38 & 25.3 \\
\hline & Broken family & 4 & 2.7 \\
\hline \multicolumn{2}{|c|}{ Duration of farming career } & \multicolumn{2}{|c|}{$32.13 \pm 1.37(\operatorname{Min}: 2 ; \operatorname{Max}: 70)$} \\
\hline \multirow[t]{4}{*}{ Agriculture Branch } & Dry farming & 83 & 55.3 \\
\hline & Irrigated farming & 46 & 30.7 \\
\hline & Vegetable \& fruit growing & 16 & 10.7 \\
\hline & Livestock & 5 & 3.3 \\
\hline \multirow{3}{*}{$\begin{array}{l}\text { Position in agriculture } \\
\text { industry }\end{array}$} & Farmer & 135 & 90.0 \\
\hline & Permanent labourer & 5 & 3.3 \\
\hline & Seasonal labourer & 10 & 6.7 \\
\hline \multirow[t]{3}{*}{ Farming Season } & Winter & 4 & 2.7 \\
\hline & Spring & 37 & 24.7 \\
\hline & Summer & 109 & 72.7 \\
\hline
\end{tabular}

Table 2. Covid-19 characteristics of agricultural labourers.

\begin{tabular}{|c|c|c|c|}
\hline \multicolumn{2}{|c|}{ Covid-19 Characteristics } & $\mathrm{n}$ & $\%$ \\
\hline \multirow[t]{2}{*}{ Being diagnosed with Covid-19 } & Yes & 2 & 1.3 \\
\hline & No & 148 & 98.7 \\
\hline \multirow[t]{2}{*}{ Having acquaintances diagnosed with Covid-19 } & Yes & 112 & 74.7 \\
\hline & No & 38 & 25.3 \\
\hline \multirow[t]{2}{*}{ Receiving information on Covid-19 } & Yes & 129 & 86.0 \\
\hline & No & 21 & 14.0 \\
\hline \multirow[t]{4}{*}{ Source of information $(n=129)$} & Healthcare professionals & 58 & 45.0 \\
\hline & Visual media & 62 & 48.1 \\
\hline & Printed media & 3 & 2.3 \\
\hline & Immediate circle & 6 & 4.7 \\
\hline \multirow[t]{2}{*}{ Considering Covid-19 as contagious } & Yes & 137 & 91.3 \\
\hline & No & 13 & 8.7 \\
\hline \multirow{2}{*}{$\begin{array}{l}\text { Observing mask wearing, social distance and } \\
\text { hygiene rules }\end{array}$} & Yes & 140 & 93.3 \\
\hline & No & 10 & 6.7 \\
\hline \multirow[t]{2}{*}{ Feeling safe against Covid-19 } & Yes & 25 & 16.7 \\
\hline & No & 125 & 83.3 \\
\hline
\end{tabular}

affected; diseases and harmful agents did not increase; difficulties in accessing to agricultural products and food were experienced and supply of production materials was affected. Furthermore, $84 \%, 63.3 \%, 70.7 \%, 84 \%, 94 \%, 93.3 \%, 62.7 \%, 97.3 \%$ and $53.3 \%$ of the participants respectively stated that Covid-19 pandemic did not affect their decision of being a grower; they had problems for accessing to production site; collaboration among the farmers was affected; they had problems for receiving technical support; they did not use different cultivation methods due to social distance; they did not get support from mobile phone for agricultural applications; their production area did not change; they believed that a food crisis would emerge and prices of meat and meat products increased.

\subsection{Comparison of current agricultural sector of} participating farmers to effects of Covid-19 pandemic on agricultural production activities

The comparison of the current agricultural sector of participating farmers to effects of Covid-19 pandemic on agricultural production activities are given in Table 4 . 
Table 3. Considerations regarding effects of Covid-19 pandemic on agricultural production activities.

\begin{tabular}{|c|c|c|c|}
\hline \multicolumn{2}{|c|}{ Considerations Regarding Effects on Production Activities } & \multirow{2}{*}{$\frac{\mathrm{n}}{132}$} & \multirow{2}{*}{$\begin{array}{c}\% \\
88.0\end{array}$} \\
\hline Worried about harvest or sales & Yes & & \\
\hline & No & 18 & 12.0 \\
\hline \multirow[t]{3}{*}{ Reasons for worrying $(\mathrm{n}=132)$} & Shrinkage in market & 40 & 30.3 \\
\hline & Instability in prices & 47 & 35.6 \\
\hline & Increase in product costs & 45 & 34.1 \\
\hline \multirow[t]{2}{*}{ Affecting production pattern } & Yes & 13 & 8.7 \\
\hline & No & 137 & 91.3 \\
\hline \multirow[t]{2}{*}{ Affecting the decision/idea of working in agriculture industry } & Yes & 64 & 42.7 \\
\hline & No & 86 & 57.3 \\
\hline \multirow[t]{2}{*}{ Delaying sowing/planting time } & Yes & 36 & 24.0 \\
\hline & No & 114 & 76.0 \\
\hline \multirow{2}{*}{ Having difficulties in working or recruiting seasonal labourers } & Yes & 120 & 80.0 \\
\hline & No & 30 & 20.0 \\
\hline \multirow[t]{2}{*}{ Affecting productivity and quality } & Yes & 106 & 70.7 \\
\hline & No & 44 & 29.3 \\
\hline \multirow[t]{2}{*}{ Increase in diseases and harmful agents } & Yes & 16 & 10.7 \\
\hline & No & 134 & 89.3 \\
\hline \multirow{2}{*}{$\begin{array}{l}\text { Believing in having difficulties in access to agricultural products } \\
\text { and food }\end{array}$} & Yes & 134 & 89.3 \\
\hline & No & 16 & 10.7 \\
\hline \multirow[t]{2}{*}{ Affecting supply of production materials } & Yes & 116 & 77.3 \\
\hline & No & 34 & 22.7 \\
\hline \multirow[t]{2}{*}{ Affecting the decision of being a grower } & Yes & 24 & 16.0 \\
\hline & No & 126 & 84.0 \\
\hline \multirow[t]{2}{*}{ Having problems for accessing to production site } & Yes & 95 & 63.3 \\
\hline & No & 55 & 36.7 \\
\hline \multirow[t]{2}{*}{ Affecting the collaboration among the farmers } & Yes & 106 & 70.7 \\
\hline & No & 44 & 29.3 \\
\hline \multirow[t]{2}{*}{ Having problems for receiving technical support } & Yes & 126 & 84.0 \\
\hline & No & 24 & 16.0 \\
\hline \multirow[t]{2}{*}{ Using different methods for cultivation due to social distance } & Yes & 9 & 6.0 \\
\hline & No & 141 & 94.0 \\
\hline \multirow[t]{2}{*}{ Getting support from smart phones for agricultural applications } & Yes & 10 & 6.7 \\
\hline & No & 140 & 93.3 \\
\hline \multirow[t]{3}{*}{ Effects on production area } & Increase in production area & 31 & 20.7 \\
\hline & Decrease in production area & 25 & 16.7 \\
\hline & No change in production area & 94 & 62.7 \\
\hline \multirow[t]{2}{*}{ Believing in outbreak of a food crisis } & Yes & 146 & 97.3 \\
\hline & No & 4 & 2.7 \\
\hline \multirow[t]{5}{*}{ Agricultural production sectors believed to have increases in prices } & Cereal group & 56 & 37.3 \\
\hline & Pulses group & 7 & 4.7 \\
\hline & Vegetables and fruits group & 4 & 2.6 \\
\hline & Milk and dairy products & 3 & 2.0 \\
\hline & Meat and meat products & 80 & 53.3 \\
\hline
\end{tabular}

It was found out by assessing the current agricultural sector of those participating in the study and effects of Covid-19 pandemic on agricultural production activities that there was a statistically significant correlation $(\mathrm{p}<0.05)$ between the current agricultural sector of the participants and worrying about the harvest and sales, reasons for worrying; affecting production pattern; having difficulties in working and recruiting seasonal laborers; believing in having difficulties in accessing to agricultural products and food, affecting production materials, using different methods for cultivation due to social distance and believing in outbreak of a food crisis. It was also identified by examining the levels of worrying about harvest and sales of the participants that those dealing with vegetable and fruit growing had higher rates of worrying about the harvest and sales. Considering the reasons for worrying and current agricultural sector, the highest worrying rate of $46.7 \%$ was detected for the vegetable and fruit growers with the belief of shrinkage in market. $97.6 \%$ of those dealing with dry farming stated that their production patterns were not affected. It was revealed that having difficulties in working and recruiting seasonal laborers 
was the case mostly for those dealing with dry farming and irrigated farming. Those dealing with dry farming formed the largest group of farmers believing in having difficulties with regards to access to agricultural products and food. Similarly, those dealing with dry farming were the farmers most affected by difficulties in supply of production materials. Those dealing with vegetable and fruit growing and livestock did not use different methods for cultivation. The belief in outbreak of a food crisis due to Covid-19 was mostly common among those dealing with dry farming (Table 4).

Table 4. Comparison of current agricultural sector of participating farmers to effects of Covid-19 pandemic on agricultural production activities.

\begin{tabular}{|c|c|c|c|c|c|c|c|}
\hline \multirow{2}{*}{\multicolumn{3}{|c|}{ Effects on Agricultural Production Activities }} & \multicolumn{5}{|c|}{ Agricultural Sector } \\
\hline & & & \multirow{2}{*}{$\begin{array}{c}\text { Dry farming } \\
72\end{array}$} & \multirow{2}{*}{$\begin{array}{l}\text { Irrigated } \\
\text { farming } \\
43\end{array}$} & \multirow{2}{*}{$\begin{array}{l}\text { Vegetable \& } \\
\text { fruit growing } \\
15\end{array}$} & \multirow{2}{*}{$\frac{\text { Livestock }}{2}$} & \multirow{2}{*}{$\begin{array}{c}\text { Total } \\
132\end{array}$} \\
\hline \multirow{7}{*}{ harvest and sales } & Yes & $\mathrm{n}$ & & & & & \\
\hline & & $\%$ & 86.7 & 93.5 & 93.8 & 40.0 & 88 \\
\hline & No & $\mathrm{n}$ & 11 & 3 & 1 & 3 & 18 \\
\hline & & $\%$ & 13.3 & 6.5 & 6.2 & 60.0 & 12 \\
\hline & Total & $\mathrm{n}$ & 83 & 46 & 16 & 5 & \\
\hline & & $\%$ & 100.0 & 100.0 & 100.0 & 100.0 & \\
\hline & Test/p & & & & $12.841 / 0.005$ & & \\
\hline \multirow{9}{*}{$\begin{array}{l}\text { Reasons for worrying } \\
(\mathbf{n}=132)\end{array}$} & Shrinkage in market & $\mathrm{n}$ & 15 & 16 & 7 & 2 & 40 \\
\hline & & $\%$ & 20.8 & 37.2 & 46.7 & 100.0 & 30.3 \\
\hline & Instability in prices & $\mathrm{n}$ & 26 & 18 & 3 & 0 & 47 \\
\hline & & $\%$ & 36.1 & 41.9 & 20.0 & 0.0 & 35.6 \\
\hline & Increase in product & $\mathrm{n}$ & 31 & 9 & 5 & 0 & 45 \\
\hline & costs & $\%$ & 43.1 & 20.9 & 33.3 & 0.0 & 34.1 \\
\hline & Total & $\mathrm{n}$ & 72 & 43 & 15 & 2 & \\
\hline & & $\%$ & 100.0 & 100.0 & 100.0 & 100.0 & \\
\hline & Test/p & & & & $14.121 / \mathbf{0 . 0 2 8}$ & & \\
\hline \multirow{7}{*}{$\begin{array}{l}\text { Affecting production } \\
\text { pattern }\end{array}$} & Yes & $\mathrm{n}$ & 2 & 9 & 1 & 1 & 13 \\
\hline & & $\%$ & 2.4 & 19.6 & 6.2 & 20.0 & 8.7 \\
\hline & No & $\mathrm{n}$ & 81 & 37 & 15 & 4 & 137 \\
\hline & & $\%$ & 97.6 & 80.4 & 93.8 & 80.0 & 91.3 \\
\hline & Total & $\mathrm{n}$ & 83 & 46 & 16 & 5 & \\
\hline & & $\%$ & 100.0 & 100.0 & 100.0 & 100.0 & \\
\hline & Test/p & & & & $11.937 / 0.008$ & & \\
\hline \multirow{7}{*}{$\begin{array}{l}\text { Having difficulties } \\
\text { in working or } \\
\text { recruiting seasonal } \\
\text { labourers }\end{array}$} & Yes & $\mathrm{n}$ & 69 & 39 & 10 & 2 & 120 \\
\hline & & $\%$ & 83.1 & 84.8 & 62.5 & 40.0 & 80 \\
\hline & No & $\mathrm{n}$ & 14 & 7 & 6 & 3 & 30 \\
\hline & & $\%$ & 16.9 & 15.2 & 37.5 & 60.0 & 20 \\
\hline & Total & $\mathrm{n}$ & 83 & 46 & 16 & 5 & \\
\hline & & $\%$ & 100.0 & 100.0 & 100.0 & 100.0 & \\
\hline & Test/p & & & & $9.229 / \mathbf{0 . 0 2 6}$ & & \\
\hline \multirow{7}{*}{$\begin{array}{l}\text { Believing in having } \\
\text { difficulties in access } \\
\text { to agricultural } \\
\text { products and food }\end{array}$} & Yes & $\mathrm{n}$ & 78 & 40 & 14 & 2 & 134 \\
\hline & & $\%$ & 94.0 & 87.0 & 87.5 & 40.0 & 89.3 \\
\hline & No & $\mathrm{n}$ & 5 & 6 & 2 & 3 & 19 \\
\hline & & $\%$ & 6.0 & 13.0 & 12.5 & 60.0 & 10.7 \\
\hline & Total & $\mathrm{n}$ & 83 & 46 & 16 & 5 & \\
\hline & & $\%$ & 100.0 & 100.0 & 100.0 & 100.0 & \\
\hline & Test/p & & & & $14.977 / \mathbf{0 . 0 0 2}$ & & \\
\hline \multirow{7}{*}{$\begin{array}{l}\text { Affecting supply of } \\
\text { production materials }\end{array}$} & Yes & $\mathrm{n}$ & 67 & 36 & 12 & 1 & 116 \\
\hline & & $\%$ & 80.7 & 78.3 & 75.0 & 20.0 & 77.3 \\
\hline & No & $\mathrm{n}$ & 16 & 10 & 4 & 4 & 34 \\
\hline & & $\%$ & 19.3 & 21.7 & 25.0 & 80.0 & 22.7 \\
\hline & Total & $\mathrm{n}$ & 83 & 46 & 16 & 5 & \\
\hline & & $\%$ & 100.0 & 100.0 & 100.0 & 100.0 & \\
\hline & Test/p & & & & $9.993 / \mathbf{0 . 0 1 9}$ & & \\
\hline \multirow{7}{*}{$\begin{array}{l}\text { Using different } \\
\text { methods for } \\
\text { cultivation due to } \\
\text { social distance }\end{array}$} & Yes & $\mathrm{n}$ & 2 & 7 & 0 & 0 & 9 \\
\hline & & $\%$ & 2.4 & 15.2 & 0.0 & 0.0 & 6 \\
\hline & No & $\mathrm{n}$ & 81 & 39 & 16 & 5 & 141 \\
\hline & & $\%$ & 97.6 & 84.8 & 100.0 & 100.0 & 94 \\
\hline & Total & $\mathrm{n}$ & 83 & 46 & 16 & 5 & \\
\hline & & $\%$ & 100.0 & 100.0 & 100.0 & 100.0 & \\
\hline & Test/p & & & & $10.167 / \mathbf{0 . 0 1 7}$ & & \\
\hline \multirow{7}{*}{$\begin{array}{l}\text { Believing in outbreak } \\
\text { of a food crisis }\end{array}$} & Yes & $\mathrm{n}$ & 83 & 45 & 14 & 4 & 134 \\
\hline & & $\%$ & 100.0 & 97.8 & 87.5 & 80.0 & 89.3 \\
\hline & No & $\mathrm{n}$ & 0 & 1 & 2 & 1 & 16 \\
\hline & & $\%$ & 0.0 & 2.2 & 12.5 & 20.0 & 10.7 \\
\hline & Total & $\mathrm{n}$ & 83 & 46 & 16 & 5 & \\
\hline & & $\%$ & 100.0 & 100.0 & 100.0 & 100.0 & \\
\hline & Test/p & & & & $14.065 / \mathbf{0 . 0 0 3}$ & & \\
\hline
\end{tabular}




\subsection{Comparison of income level to effects of Covid-19 pandemic on agricultural production activities}

The comparison of the income level of those participating in the study to the effects of Covid-19 pandemic on agricultural production activities are given in the Table 5 .
The income level of those participating in the study was compared to the effects of Covid-19 pandemic on agricultural production activities. According to the analyses performed, it was found out $93.2 \%, 85.4 \%, 95.1 \%, 85.4 \%$ and $89.3 \%$ of those having incomes exceeding their expenses worried about the harvest

Table 5. Comparison of income level with effects of Covid-19 pandemic on agricultural production activities.

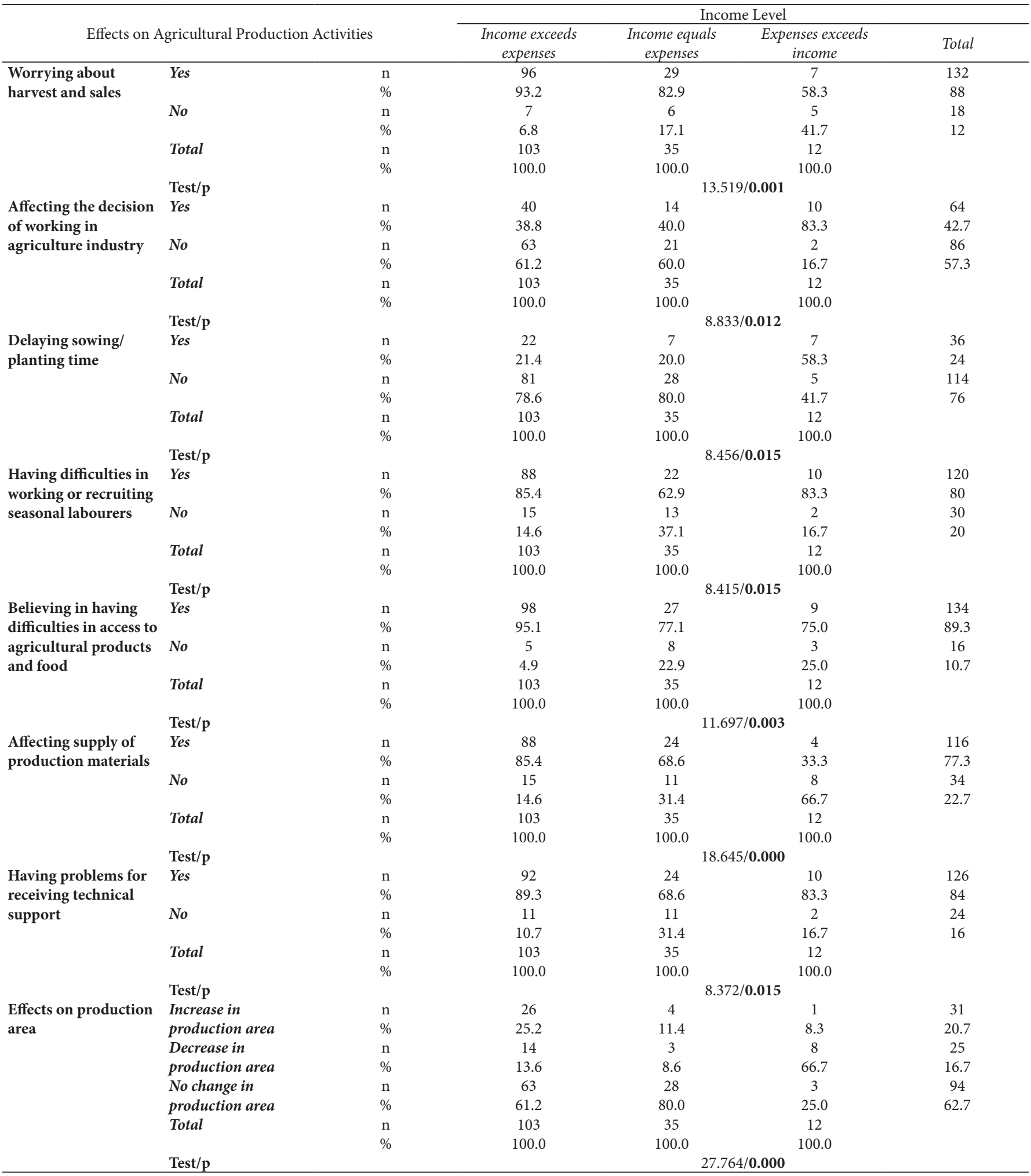


Table 5. Continued...

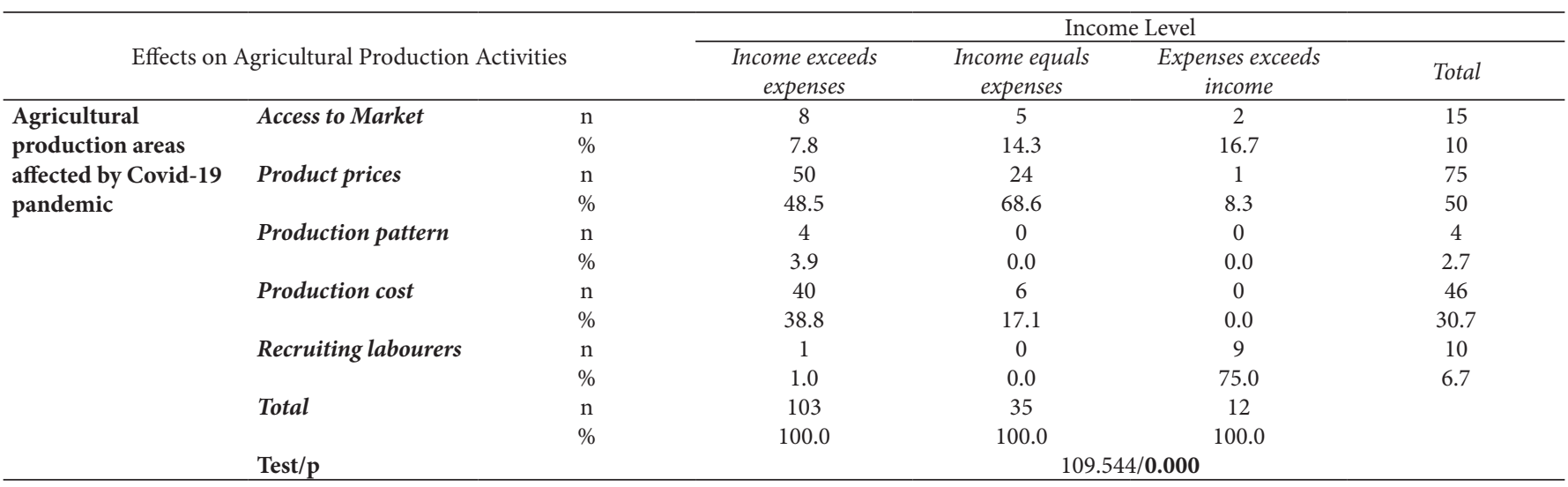

and sales, they had difficulties in working or recruiting seasonal laborers, they had difficulties in accessing to agricultural products and food, supply of production materials was affected and they had problems or receiving technical support respectively. It was found out for those having incomes equaling their expenses that Covid-19 pandemic did not delay their sowing/planting time for $80 \%$ of them and the production area of $80 \%$ of these farmers did not change. It was also revealed that the decision of working in agricultural sector was affected and problems in recruiting laborers were experienced during the Covid-19 pandemic for respectively $83.3 \%$ and $75 \%$ of those having expenses exceeding their income.

\section{Discussion}

The Covid-19 pandemic is a disease continuing to affect the entire world at different scales. Every country/society or even every individual has been affected by the pandemic depending on his/her living conditions. Those, who have to go outside due to different reasons, face a higher risk of being infected with virus. Agricultural production is generally performed on lands away from houses and sometimes requires travel to different cities. During the pandemic, this mobility poses a risk for both sustainability of agricultural production and protection of public health. In Turkey, 50\% of tea producers (Ergun, 2019) and 5\% of hazelnut producers (Demir, 2018) live in a city different from where his/her land is located and only visit the land during the harvesting period. Similarly, the labour recruited from other cities is used for harvesting of these products to a great extent. This led to an increase in infection risk (cases) in production areas in summer when the agricultural products were harvested.

Certain results of this study, by which we evaluated effects of the Covid-19 pandemic on agricultural laborers and activities, have drawn our interest. The participants of our study were mostly middle aged men with low educational levels and nuclear families. In Konya province, mostly dry farming is preferred and the labour is actively used in summer due to land structure and ecological factors. In a study researching effects of ads in the media on the farmers in Konya, 51.4\% of the participants were primary school graduate (Yaral1, 2018). Similarly, $58.09 \%$ of the participants were primary school graduates in a study on grain corn producers in Konya (Bozdemir, 2017). The educational status of those participating in our study was mostly consistent with the existing literature. It was found out in our study that only $1.3 \%$ of the agricultural laborers were diagnosed with Covid- 19 but $74.7 \%$ had acquaintances diagnosed with the disease. The fact that their acquaintances' having quite higher rates of Covid-19 diagnoses may be explained with strong social bonds and high awareness. The level of knowledge regarding Covid-19 was measured to be higher and the farmers mostly got information from visual media. We believe that the visual medias being the primary source of information on Covid-19 is caused by the fact that it can be accessed more easily compared to alternative sources of information. The rate of those considering Covid-19 as a contagious disease and observing mask-wearing, social distance and hygiene rules was measured to be quite high and this indicates a high level of social awareness regarding infection of the disease. On the other hand, the rate of those not observing the social distance and cleaning rules $(6.6 \%)$ hints that training efforts should be increased to prevent contagion of the pandemic. As the rate of those feeling themselves safe during the Covid-19 pandemic was measured to be low, providing psychological support for agricultural laborers may be useful.

It was found out that the rate of worrying about the harvest and sales during the Covid-19 pandemic was high among the agricultural laborers. Among the reasons for worrying, price instability ranked first with a small margin but shrinkage in market, increase in product costs and price instability had similar shares. Due to these worries, the decision/idea of working in agriculture industry was highly affected and $97.3 \%$ of the agricultural laborers believed that a food crisis would erupt during the pandemic. The agricultural laborers stated that they had difficulties in recruiting seasonal laborers, accessing to production site and receiving technical support and the productivity and quality were affected, collaboration among farmers were affected and meat and meat product prices increased due to direct and indirect effects of the pandemic. In a study conducted in China, it was stated that the pandemic process was affected by $31.41 \%$ of daily agricultural activities (Du et al., 2020). The pandemic's hindering agricultural labour supply affect labor-intensive irrigated farming to the greatest extent. In strawberry cultivation, which has intensive use of labour in the harvest due to lack of labour, harvests were delayed and the crops rotted in the field (Gu \& Wang, 2020). Zhou et al. (2020) states that $70 \%$ of the farms in which workforce 
is used in China, especially in the spring, are affected by daily production and operating activities, and transportation to the land, labour and material transfers are blocked due to travel restrictions due to the pandemic. It is stated that difficulties in labour supply were experienced due to Covid-19 cases among farm and packing house laborers in USA and fresh production would be affected by this difficulty. It is also mentioned that the social distance could not be kept in packing houses although social distance measures could be taken for farming and harvesting activities. At the end of May 2020, more than 600 Covid-19 cases were observed among agricultural laborers in Yakima County, Washington and it was found out that $62 \%$ of the patients were laborers working in apple industry, other packing houses or warehouses (Rosenberg et al., 2020).

The Covid-19 pandemic mostly affected agricultural production in terms of product prices and this impact is more apparent in irrigated farming. Secondly, production costs were affected and this effect was measured to be higher in irrigated farming. Similarly, problems were experienced for supply of production materials, accessing to production site, collaboration among farmers and receiving technical support and this indicates the high level of difficulties experienced in agricultural production. On the other hand, problems such as change in production area, effects on product pattern, affecting the decision of production and diseases and pests in production were mentioned less frequently.

A correlation between the current agricultural sector of the participants and their level of worrying about the harvest and sales was detected and it the rate of worrying about the harvest and sales was measured to be higher among those dealing with vegetable and fruit growing. We believe that vegetables and fruits' being perishable products impacted this result. Partial or substantial deterioration was reported for $86 \%$ of Canadian vegetable and fruit supply chain. In this regard, recruiting and planning the labour and ensuring safety of the laborers drew our interest as the most common concerns (Richards \& Rickard, 2020). However, retail food sales increased by $10.06 \%$ in total and $4.5 \%$ for fresh products in certain states of USA which is the country struck by the pandemic hardest (Nickle, 2020). The concerns of vegetable and fruit producers despite increasing sales are related to harvesting of the products and problems regarding reaching to the end consumers depending on the restrictions imposed on marketing channels. On the other hand, increase in product costs and price instabilities were also among the most common reasons for concern. In China, the tendency to be more affected has been observed in vegetable producers in places where pandemic restrictions are more. This situation is caused by further sales contraction, price instabilities and supply chain disruptions (Zhou et al., 2020). The increase in consumption of fresh products may increase the income of the producers due to the possible shortage of production due to the anxiety caused by the restrictions. Those dealing with dry and irrigated farming had more difficulties in working and recruiting laborers due to the effects of the pandemic. The fact that problems experienced in accessing to agricultural products and food and supply of production materials were more common among those dealing with dry farming may be related to seasonal input stocking due to slower input mobility compared to other agricultural sectors.
Probably due to such difficulties, the belief in outbreak of a food crisis was more common among those working in dry farming.

Among the agricultural laborers having incomes exceeding their expenses, problems related to input use, production, harvest, technical support and sales were more common probably due to their having larger lands. On the contrary, concerns for working were more common for the agricultural laborers having expenses exceeding their incomes and they also had difficulties in recruiting seasonal laborers possibly due to lower number of permanent laborers employed by them. It is mentioned that the Covid-19 crisis damaged the large-scale agricultural enterprises in India due to safety concerns regarding agricultural supply chains and exhausted labour. It is also stated that dairies, flower producing, fruit growing, fishery and poultry farming were the most affected sectors. Due to long-term unemployment, problems were experienced for food supply in rural areas (Kumar et al., 2020). It is recommended to implement new strategies including provision of certain cash incentives for the farmers not to burn paddy husk due to economic difficulties caused by Covid-19 in India. It is stated that such a strategy is both required for public health and sustainability of the ecosystem and it will contribute to adoption of the sectors to sustainable production technologies and diversification of products (McDonald et al., 2020). In China, municipalities' practices in the form of "shopping basket programs" help to provide vegetable production and vegetable supply to cities (Gu \& Wang, 2020). It is also stated that the Covid-19 outbreak disturbed the food supply chain. In a study examining the epidemic process in terms of exporting companies, the top five challenges faced by exporting companies in China were increasing export costs, financing difficulties, blocked logistics and transportation, labour shortage and order cancellations (Huang, 2020). Despite the decrease in vegetable prices during the pandemic, e-commerce was not affected much by this situation. More products need to be insured and e-commerce applications need to be increased in order to reduce the effects in the supply chain (Gu \& Wang, 2020). Therefore, strengthening local food production at household and community level is considered to be critical and it is anticipated that fresh food production can be supported to a certain degree by supporting household production. It is considered that household production may positively contribute in the process as an agricultural system combining different physical, social and economic functions on the land around the house of a family (Lal, 2020). There are various areas, in which problems are observed, during the Covid-19 pandemic affecting all social areas. Therefore, it is required to take the measures protecting the health of those working in agriculture and thus ensuring safe working environments and safe food production in order to contain the outbreak swiftly and normalize the social life (Mishra et al., 2021).

\section{Conclusion}

Direct effects of the pandemic on the agriculture industry and uncertainties brought by it have led to unfavorable situations for the agricultural laborers at both an individual level and in terms of agricultural activities/production. Covid-19 undermined the one's feeling himself/herself safe and brought along concerns regarding production and marketing channels, risk of accessing to 
food, difficulties in working and recruiting laborers and problems for input supply. This may affect the agricultural production and marketing channels to a larger extent. Considering the incoming winter season, food delivery and access to safe food may get difficult especially in metropolises due to decreases in fresh vegetable and fruit production. During this process, the decision makers / executives should take measures that will protect the health of agricultural laborers as is the case for all sectors during the Covid-19 pandemic and provide them with material support and moral support such as training, technical support and social programs. Receiving the opinions of the relevant stakeholders will assist in achieving the goals more easily while making a decision. Specific to agriculture industry, incentives for packing and short and long term storage in fresh vegetable and fruit supply chains which show fragility and increasing the agricultural support shall provide significant contributions to the agricultural production in both short and long terms. Licensed warehousing operations can be made more active for possible increases in demand for dried, frozen and canned products. The uncertainties experienced during the pandemic should be considered as an opportunity to popularize and strengthen the producer associations. Ever-increasing and continuing uncertainties may lead to adaptation of agricultural laborers to organizations such as unions and cooperatives more easily. Meanwhile, living conditions of the seasonal laborers may be obligatorily improved within the scope of the measures against the outbreak.

Considering the national and global agricultural production and consumption perspectives, the measures minimizing the possible risks against the production should be taken. Information and communication technologies should be used for agricultural production and marketing channels to popularize the newly developed techniques and agricultural practices as fast and effective as possible. The Covid-19 pandemic leading to emergence of various problems may cause to a better understanding of the significance of accessing to safe and sufficient food. On the other hand, the Covid-19 pandemic will contribute to prominence of self-sufficiency policies for food production for the countries. It will accelerate development and implementation of the policies supporting maintenance of agricultural production in the rural areas and vicinity of the metropolises. Especially the municipalities' taking action and incentivizing production of highly-consumed products and pulses with purchasing guarantees is considered to be significant. In addition, these agricultural products' being distributed to the families of lower income groups and those losing their jobs or having less labour will provide significant contributions for the social life and management of the pandemic.

\section{Conflict of interest}

The authors declare no conflict of interest.

\section{References}

Barichello, R. (2020). The COVID-19 pandemic: anticipating its effects on Canada's agricultural trade. Canadian Journal of Agricultural Economics, 68(2), 219-224. http://dx.doi.org/10.1111/cjag.12244.
Bozdemir, M. (2017). Determination of the resource utilization efficiency in maize production: case of Konya Province (Master's thesis). Selçuk University, Institute of Science and Technology, Konya, Turkey.

Dean, A. G., Sullivan, K. M., \& Soe, M. M. (2021). OpenEpi: Open source epidemiologic statistics for public health, version. Retrieved from https://www.OpenEpi.com

Demir, I. (2018). Costs and efficiency in hazelnut farming: a stochastic frontier analysis on the effects of number of lots. Journal of Turkish Studies, 13, 619-639. http://dx.doi.org/10.7827/TurkishStudies.14141.

Du, Z. X., Lai, X. D., Long, W. J., \& Gao, L. L. (2020). The short-and long-term impacts of the COVID-19 pandemic on family farms in China-Evidence from a survey of 2324 farms. Journal of Integrative Agriculture, 19(12), 2877-2890. http://dx.doi.org/10.1016/S20953119(20)63390-1.

Ergun, B. (2019). Agricultural producer cooperatives in Turkey: an analysis from tea example (Master's thesis). Ordu University, Institute of Social Sciences, Ordu, Turkey.

Finger, R., \& Schmid, S. (2008). Modeling agricultural production risk and the adaptation to climate change. Agricultural Finance Review, 68(1), 25-41. http://dx.doi.org/10.1108/00214660880001217.

Fróna, D., Szenderák, J., \& Harangi-Rákos, M. (2019). The challenge of feeding the world. Sustainability, 11(20), 5816. http://dx.doi. org/10.3390/su11205816.

Gu, H. Y., \& Wang, C. W. (2020). Impacts of the COVID-19 pandemic on vegetable production and countermeasures from an agricultural insurance perspective. Journal of Integrative Agriculture, 19(12), 2866-2876. http://dx.doi.org/10.1016/S2095-3119(20)63429-3.

Huang, J. K. (2020). Impacts of COVID-19 on agriculture and rural poverty in China. Journal of Integrative Agriculture, 19(12), 28492853. http://dx.doi.org/10.1016/S2095-3119(20)63469-4.

Karlsson, M., Nilsson, T., \& Pichler, S. (2014). The impact of the 1918 Spanish flu epidemic on economic performance in Sweden - an investigation into the consequences of an extraordinary mortality shock. Journal of Health Economics, 36, 1-19. http://dx.doi.org/10.1016/j. jhealeco.2014.03.005. PMid:24721206.

Kerkhoven, R. (1997). The effects of HIV/AIDS on farming systems in eastern Africa. Southern Africa AIDS Information Dissemination Service Bulletin, 5(2), 13-14. PMid:12222360.

Konapala, G., Mishra, A. K., Wada, Y., \& Mann, M. E. (2020). Climate change will affect global water availability through compounding changes in seasonal precipitation and evaporation. Nature Communications, 11(1), 1-10. http://dx.doi.org/10.1038/s41467020-16757-w. PMid:32576822.

Konya. (2020). Agriculture and Livestock. Mevlana Development Agency, Konya Provincial Directorate of Agriculture and Forestry. Retrieved from http://www.konyadayatirim.gov.tr/sektor.asp?SayfaID=7

Kumar, A., Padhee, A. K., \& Kumar, S. (2020). How Indian agriculture should change after COVID-19. Food Security, 12(4), 837-840. http://dx.doi.org/10.1007/s12571-020-01063-6. PMid:32837635.

Lal, R. (2020). Home gardening and urban agriculture for advancing food and nutritional security in response to the COVID-19 pandemic. Food Security, 12(4), 1-6. http://dx.doi.org/10.1007/s12571-02001058-3. PMid:32837634.

Lopez-Ridaura, S., Barba-Escoto, L., Reyna, C., Hellin, J., Gerard, B., \& Van Wijk, M. (2019). Food security and agriculture in the Western Highlands of Guatemala. Food Security, 11(4), 817-833. http://dx.doi. org/10.1007/s12571-019-00940-z.

Masood, A., Ellahi, N., \& Batool, Z. (2012). Causes of low agricultural output and impact on socio-economic status of farmers: A case study of rural Potohar in Pakistan. International Journal of Basic 
and Applied Science, 1(2), 343-351. http://dx.doi.org/10.17142/ ijbas-2012.1.2.21.

McDonald, A. J., Jat, M. L., Craufurd, P., Hellin, J., Hung, N. V., Keil, A., Kishore, A., Kumard, V., McCarty, J.L., Pearson, P., Samaddar, A., Shyamsundar, P., Shirsath, P.B., Sidhu, H.S., Singh, A.K., Singh, S., Srivastava, A.K., \& Gerard, B. (2020). Indian agriculture, air pollution, and public health in the age of COVID. World Development, 135, 105064 .

Mishra, A., Bruno, E., \& Zilberman, D. (2021). Compound natural and human disasters: managing drought and COVID-19 to sustain global agriculture and food sectors. The Science of the Total Environment, 754, 142210. http://dx.doi.org/10.1016/j.scitotenv.2020.142210. PMid:32920415.

Nesheim, M. C., Oria, M., \& Yih, P. T. (2015). A framework for assessing effects of the Food System (pp. 167-232). Washington DC: The National Academies Press (US). Social and economic effects of the US Food System.

Nickle, A. (2020, March 20). Retail produce sales rising amid coronavirus concerns. The Packers. Retrieved from https://www.thepacker.com/ article/retail-produce-sales-rising-amid-coronavirus-concerns

Obrizan, M., Karlsson, M., \& Matvieiev, M. (2020). The Macroeconomic Impact of the 1918-19 Influenza Pandemic in Sweden. MPRA Paper No. 98910. Munich: Munich University Library, Munich Personal RePEc Archive. Retrieved from https://mpra.ub.uni-muenchen.de/98910

Popp, J., Lakner, Z., Harangi-Rakos, M., \& Fari, M. (2014). The effect of bioenergy expansion: food, energy, and environment. Renewable \& Sustainable Energy Reviews, 32, 559-578. http://dx.doi.org/10.1016/j. rser.2014.01.056.

Poudel, P. B., Poudel, M. R., Gautam, A., Phuyal, S., Tiwari, C. K., Bashyal, N., \& Bashyal, S. (2020). COVID-19 and its global impact on food and agriculture. Journal of Biology and Today's World, 9(5), 221-225.

Richards, T. J., \& Rickard, B. (2020). COVID-19 impact on fruit and vegetable markets. Canadian Journal of Agricultural Economics, 68(2), 189-194. http://dx.doi.org/10.1111/cjag.12231.

Roell, M. S., \& Zurbriggen, M. D. (2020). The impact of synthetic biology for future agriculture and nutrition. Current Opinion in Biotechnology,
61, 102-109. http://dx.doi.org/10.1016/j.copbio.2019.10.004. PMid:31812911.

Rosenberg, M., Cooke, K., \& Walljasper, C. (2020). Coronavirus spreads among fruit and vegetable packers, worrying U.S. officials. Reuters New York/Los Angeles/Chicago. Retrieved from https://www.reuters. com/article/us-health-coronavirus-usa-farmworkers

Sharma, R., Shishodia, A., Kamble, S., Gunasekaran, A., \& Belhadi, A. (2020). Agriculture supply chain risks and COVID-19: mitigation strategies and implications for the practitioners. International Journal of Logistics Research and Applications, 1-27.

Steege, A. L., Baron, S., Davis, S., Torres-Kilgore, J., \& Sweeney, M. H. (2009). Pandemic influenza and farmworkers: the effects of employment, social, and economic factors. American Journal of Public Health, 99(Suppl. 2), S308-S315. http://dx.doi.org/10.2105/ AJPH.2009.161091. PMid:19797742.

Tao, F., Yokozawa, M., Hayashi, Y., \& Lin, E. (2003). Changes in agricultural water demands and soil moisture in China over the last half-century and their effects on agricultural production. Agricultural and Forest Meteorology, 118(3-4), 251-261. http://dx.doi.org/10.1016/ S0168-1923(03)00107-2.

Vass, J. (2005). The impact of HIV/AIDS on the labour market. South Africa: Employment \& Economic Policy Research Programme, Human Sciences Research Council.

Were, M., \& Nafula, N. N. (2003). An assessment of the impact of HIV/ AIDS on Economic Growth: the case of Kenya. Cesifo Working Paper No. 1034. Munich: CESifo.

World Health Organization - WHO. (2021). Coronavirus disease (COVID-19) dashboard. Retrieved from https://covid19.who.int/table

Yaral, M. C. (2018). The effects of local media agricultural adverts on the farmers (Master's thesis). Konya: KTO Karatay University, Institute of Social Sciences.

Zhou, J., Han, F., Li, K., \& Wang, Y. (2020). Vegetable production under COVID-19 pandemic in China: an analysis based on the data of 526 households. Journal of Integrative Agriculture, 19(12), 2854-2865. http://dx.doi.org/10.1016/S2095-3119(20)63366-4. 